\title{
Spontaneous uterine rupture in a patient who had previously undergone laparoscopic myomectomy (Case report)
}

\author{
Wachyu Hadisaputra
}

\begin{abstract}
Abstrak
Tulisan ini membahas dan melaporkan ruptura uteri saat kehamilan dan persalinan pada kasus pasca miomektomi perlaparoskopi. Laporan kasus kejadian ruptur uterus pada pasien yang sebelumnya mengalami laparoskopi operatif miomektomi miom intramural $\varnothing$ $3.5 \mathrm{~cm}$, yang 6 bulan kemudian mengalami kehamilan. Tidak ada gejala ke arah ruptura uteri saat kehamilan namun pada saat usia gestasi 34 minggu, pasien mengalami gejala ruptura uteri. Pada saat laparotomi; ditemukan fetus 2100 gram mati, dan robekan jaringan $5 \mathrm{~cm}$ pada sikatriks bekas miomektomi. Pada pasien yang mengalami miomektomi per laparoskopi khususnya miom intramural mempunyai risiko ruptura uteri pada saat persalinan. (Med J Indones 2005; 14: 113-6)
\end{abstract}

\begin{abstract}
Following laparoscopic myomectomy, uterine rupture during pregnancy or delivery in the area of the scar is a very rare but dangerous complication. Individual cases of uterine rupture during pregnancy are described in the literature. Case report of uterine rupture during delivery in a patient who had previously undergone laparoscopic myomectomy. In the case presented here, the patient conceived 6 months after an $3.5 \mathrm{~cm}$ intramural myoma, had been laparoscopically removed. No symptoms suggesting uterine rupture were observed during the pregnancy, but in the first stage of delivery the condition of the patient deteriorated and symptoms of oligaemic shock developed. A laparotomy was performed, which showed the presence of $2100 \mathrm{gr}$ fresh dead fetus in the abdominal cavity and ruptured uterine muscle in the scarred area about $5 \mathrm{~cm}$. In patients who have previously undergone a laparoscopic myomectomy, there is some risk of uterine rupture at delivery. This is also the case where unappropriate suturing of the uterine muscle had been required. (Med J Indones 2005; 14: 113-6)
\end{abstract}

Keywords: delivery, infertility, laparoscopic myomectomy, uterine rupture.

Uterine rupture during pregnancy or delivery in a woman who has previously undergone laparoscopic myomectomy is very rarely observed, but it is a dangerous complication both for the mother and her fetus. The literature reports describe individual cases of uterine rupture during pregnancy, which required surgical intervention. ${ }^{1-3}$

In recent years, thanks to the development of endoscopic techniques, laparoscopic myomectomy has become an effective procedure, replacing the classical laparotomy which is still, however, used in many centres. ${ }^{4}$ There are indications for a myomectomy procedure which

Division of Human Reproduction, Department of Obstetrics and Gynaecology Faculty of Medicine University of Indonesia, Jakarta conserves the uterus, both in infertile women and in any potential mother. Rosenfeld ${ }^{5}$ recommends this procedure in all patients treated for infertility for more than 2 years. Others ${ }^{6,7}$ suggest that myomectomy should be performed before selecting patients for in vitro fertilization. The effectiveness of laparoscopic myomectomy measured by the number of subsequent pregnancies ranges from $44 \%$ to $62 \%$. Therefore, myomectomy seems to be a method of choice, particularly when other causes of infertility have been excluded. Hasan et al ${ }^{8}$ reported that $43 \%$ of women of childbearing age with a diagnosis of uterine myoma were treated for infertility for at least 2 years. Myomas are likely to reduce the contractility of the uterus and hinder sperm migration, and the vascular changes within myomas interfere with embryo implantation. ${ }^{9}$ the methods of treatment alternative to surgical procedures include myolysis, cytomyolysis and myoma embolization. ${ }^{10-12}$ The most common and 
effective method is still surgical treatment. However, laparoscopic myomectomy involves a potential risk of uterine rupture in those patients who become pregnant after the elimination of the uterine factor in their infertility.

\section{CASE REPORT}

A 32-year-old woman was admitted to hospital for the diagnosis and treatment of one year of infertility. Gynaecological and ultrasound examinations showed a tumor of about $3.5 \mathrm{~cm}$ in size originating in the uterus, most probably a intramural myoma. The laparoscopic procedure revealed a intramural myoma which originated in the anterior wall. It was $3.5 \mathrm{~cm}$ in diameter. No lesions were found on the ova. During the operation the myoma was cut off using bipolar scissors (Figure 1). The myoma removal site was sutured using no. 3 vicryl sky needle (Figure 2); the bleeding sites were coagulated using a bipolar rod. The myoma was removed using a tissue morcellator and sent for histopathological examination. The procedure was uneventful, and the patient was discharged on the 2 nd postoperative day.

The patient spontaneously conceived 6 months later. The course of pregnancy was normal and at the 32nd week of pregnancy the patient underwent a course of steroids (Celestone). The delivery began with regular contractions on 20 November 2004. The diagnose established as $34^{\text {th }}$ week of pregnancy the first stage of delivery. She received betamethason $12.5 \mathrm{mg}$ intravenously as an effort of lung maturation an plan to perform Caesarean section 6 hours after administered of steroid.

But two hours prior to the time of Caesarean section patient was suffering of abdominal pain than immediately sent to operating theatre to undergoes Caesarean section Laparotomycally found fresh died baby in abdominal cavity, weighing 2100 gram, the placenta did not detach and it was removed manually.

The $5 \mathrm{~cm}$ rupture of the muscle occurred in the area of the scar left by laparoscopic myomectomy 14 months earlier. Then the muscle was sewn with a single continuous suture. The patient's postoperative condition was good, her haemoglobin level decreased by $2 \%$ compared with the preoperative period, and she was given oral ferrus preparations. The patient was discharged in good condition on the 4th postoperative day.

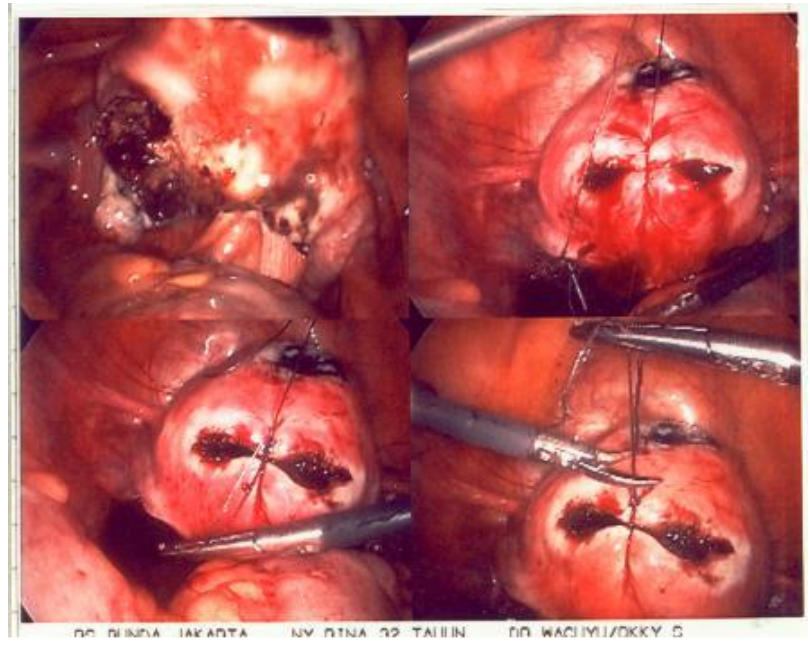

Figure 1. A $3.5 \mathrm{~cm}$ of intramural myoma was enucleated

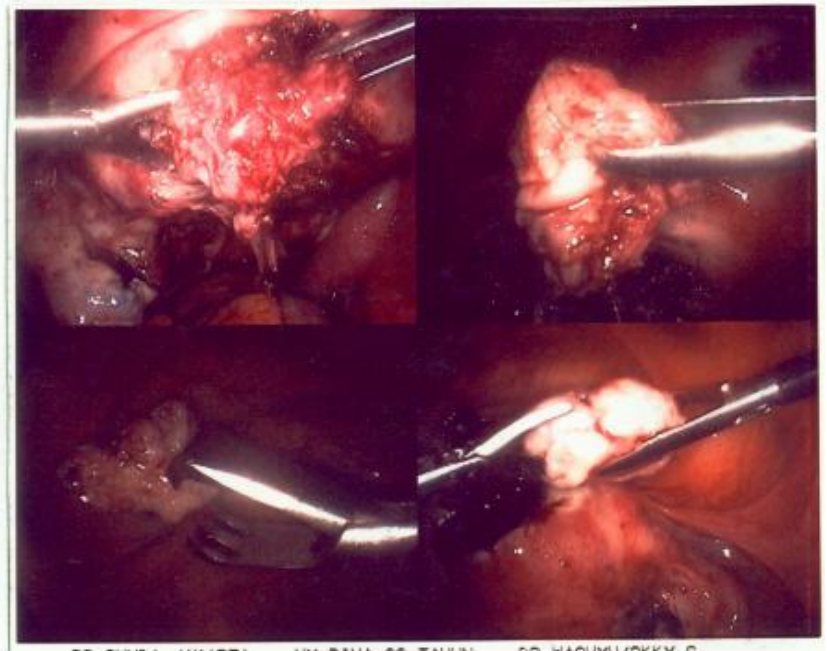

Figure 2. The myoma removal site was sutured using no. 3 of Vicryl

\section{DISCUSSION}

Both laparoscopic and classical myomectomy procedures can lead to the complication of uterine rupture, in the area of the scar, during pregnancy or delivery. Because of the recent progress in endoscopic techniques, laparoscopic myomectomy is becoming an increasingly common method of conservative treatment for uterine myomas. The procedure should be carried out by experienced operators and is believed to be difficult, especially where large intramural myomas requiring endoscopic sutures of the uterine muscle are involved. 
In the literature, individual cases are described of spontaneous rupture of the uterus during pregnancy in the scar area left by a previous laparoscopic myomectomy. ${ }^{1,3,13}$ In the case presented here, the pregnancy developed normally without any risk for the mother and fetus. This complication was first reported and described by Harris ${ }^{2}$ in 1992; in that patient, uterine rupture occurred at die 34th week of a pregnancy which occurred after the removal of a myoma from the posterior wall. Dubuisson et $a l^{14}$ reported that among 100 pregnancies following laparoscopy, spontaneous rupture of the uterus developed in only one case. The rupture occurred at 32 weeks, and die patient had previously undergone operation for an intramural myoma that was $30 \mathrm{~mm}$ in diameter, Paleosi ${ }^{3}$ described a similar case of rupture of the uterus at 32 weeks in a patient who had previously undergone laparoscopic removal of a subserous myoma that was $50 \mathrm{~mm}$ in diameter (in this case the infant died). Friedmann et al. ${ }^{10}$ presented a case of uterine rupture at the $28^{\text {th }}$ week of a pregnancy which followed laparoscopic removal of an intramural myoma of $5 \mathrm{~cm}$ in diameter; the baby was delivered in good condition by Caesarean section. Mecke et al. ${ }^{15}$ also described uterine rupture at the 30th week of a pregnancy that followed removal of an intramural myoma of $3 \mathrm{~cm}$ in diameter. The operative treatment of subserous myomas seems to involve a lower risk of uterine rupture, as reconstruction of die uterine muscle is not necessary.

Many authors have not found such complications after laparoscopic myomectomy. ${ }^{9,} 4,16$ Advances in laparoscopic techniques and the greater skills of operators have favourably affected the complication rate. Moreover, it is, interesting that die majority of pregnancies following laparoscopic myomectomy are completed by Caesarean section, which probably explains the lack of reports of uterine rupture during delivery.

In the case described here, the risk of uterine rupture was observed throughout the pregnancy. The spontaneous rupture of the uterus, which occurred in the 34 weeks of pregnancy, was quickly detected and surgically treated. The complication might have been related to the extreme shortness of the period between die operation and conception (6 months) and to the fact that die site where the myoma was removed. Paleosi ${ }^{3}$ has also observed uterine rupture after the removal of a subserous myoma where the site was not sutured; however, in the majority of cases ${ }^{1,10,15}$ such complications have followed the removal of intramural myomas of at least $3 \mathrm{~cm}$ in size.
The treatment of infertility by laparoscopic myomectomy gives the patient a chance of conception and pregnancy. Seinera $e t a l^{4}$ reported 65 pregnancies among 182 patients who had undergone die operation, and in $91 \%$ of these women the pregnancies were full term, and $80 \%$ underwent Caesarean section. Adhesions in the myomectomy region were found in only one patient. No spontaneous rupture of the uterine muscle following laparoscopic myomectomy was observed. Another group of authors ${ }^{16}$ reported 40 pregnancies among 115 patients who had had die procedure: 10 patients miscarried, 22 underwent Caesarean section, and no cases of spontaneous rupture of the uterus were observed. The average time between the procedure and conception was 43 months (9-99 months).

Laparoscopic myomectomy is an operative procedure which enables patients treated for infertility to conceive. Similarly to other operations, the procedure involves a risk of complications and failures. Subsequent ruptures of the uterine muscle during pregnancy and delivery are extremely rare. Therefore, it appears that this method should be recommended as the approach to myoma treatment in infertile patients.

\section{CONCLUSIONS}

In patients who have previously undergone a laparoscopic myomectomy, there is some risk of uterine rupture at delivery. This is also the case where unappropriate suturing of the uterine muscle had been required.

\section{REFERENCES}

1. Dubuisson J, Chavet X, Chapron C. Uterine rupture during pregnancy after laparoscopic myomectomy. Human Reprod 1995; 10: 1475-7.

2. Harris W. Uterine dehiscence following laparoscopic myomectomy. Obstet Gynecol 1992; 80: 545-6.

3. Paleosi M. Spontaneous uterine rupture at thirty-three weeks subsequent to previous superficial laparoscopic myomectomy. Amer J Obstet Gynecol 1997; 177: 1547-9.

4. Seinera P. Farina C, Todros T. Laparoscopic myomectomy and subsequent pregnancy: results in 54 patients. Human Reprod 2000; 15: 1993-6.

5. Rosenfeld D. Abdominal myomectomy for otherwise unexplained infertility. Fertil Steril 1986; 46: 328-30.

6. Stovall D, Parrish S, Van Voorhis B. Uterine leiomyomas reduce the efficacy of assisted reproduction cycles: results of a matched follow-up study. Human Reprod 1998; 13: 192-7.

7. Strandell A, Bryman I, Janson P. Background factors and scoring systems in relation to pregnancy outcome after fertility surgery. Acta Obstet Gynecol Scand 1995; 74: 281-7. 
8. Hasan F, Arumugam K, Sivanesaratnam V. Uterine leiomyomata in pregnancy. Int J Gynecol Obstet 1991; 34: 45-8.

9. Ribeiro S, Reich H, Rosenberg J. Laparoscopic myomectomy and pregnancy outcome in infertile patients. Fertil Steril 1999; 71: 571-4.

10. Friedmann W, Maier R, Luttkus A. Uterine rupture after laparoscopic myomectomy. Acta Obstet Gynecol Scand 1996; 75: 683-4.

11. Goldfarb H. YAG laser laparoscopic coagulation of symptomatic myomas. Reprod Med 1992; 37: 636-8.

12. Zreik T, Rutherford T, Plater S. Cryomyolysis, a new procedure for the conservative treatment of uterine fibroids. J Amer Assoc Gynecol Laparosc 1998; 5: 33-8.
13. Goodwin S, Vedantham S, McLucas B. Preliminary experience with uterine artery embolization for uterine fibroids. J Vasc Intervent Radiol 1997; 8: 517-26.

14. Dubuisson J, Fauconnier A, Deffarges J. Pregnancy outcome and deliveries following laparoscopic myomectomy. Human Reprod 2000; 15: 869-73.

15. Mecke H, Wallas F, Brocker A. Pelviskopische Myomenukleation: Technik, Grenzen, Komplicationen. Geburts Frauenheil 1995; 55: 374-9.

16. Nezhat C, Nezhat F, Roemisch M. Pregnancy following laparoscopic myomectomy: preliminary results. Human Reprod 1999; 14: 1219-21. 